\title{
Pelagic-benthic coupling on the shelf of the northern Bering and Chukchi Seas. I. Food supply source and benthic biomass
}

\author{
Jacqueline M. Grebmeier*, C. Peter McRoy, Howard M. Feder \\ Institute of Marine Science, University of Alaska Fairbanks, Fairbanks, Alaska 99775-1080, USA
}

\begin{abstract}
The shelf waters of the northern Bering and Chukchi Seas are ice-covered for 7 mo of the year, but despite this harsh environment, they are characterized by high benthic biomass. Coupling between water column primary production and the benthos was investigated in summers 1984 to 1986 by measurements of sediment characteristics in relation to those of the water column. Low surface sediment $\mathrm{C} / \mathrm{N}$ ratios (5.8 to 7.6 ) suggested a higher quality, nitrogen-rich marine carbon supply to the benthos in the highly productive (ca 250 to $300 \mathrm{~g} \mathrm{C} \mathrm{m}^{-2} \mathrm{yr}^{-1}$ ) Bering Shelf-Anadyr Water (BSAW) compared to lower quality, higher $\mathrm{C} / \mathrm{N}$ ratios $(7.7$ to 14.0) in sediment under the less productive (ca $50 \mathrm{~g}$ $\mathrm{C} \mathrm{m}^{-2} \mathrm{yr}^{-1}$ ) Alaska Coastal Water (ACW). Stable carbon isotope ratios suggested a marine origin for organic matter in BSAW compared to a mixture of marine and terrestrial input in ACW. Mean benthic biomass was significantly different between water locations, with mean benthic biomass decreasing from $20.2 \mathrm{~g} \mathrm{C} \mathrm{m}^{-2}$ under BSAW to $6.3 \mathrm{~g} \mathrm{C} \mathrm{m}^{-2}$ under ACW Summer benthic biomass remained seasonally constant for the 3 yr. Benthic communities underlying BSAW received a high quality marine food supply on a regular basis interannually, while those in ACW received an interannually variable amount of terrigenous organic matter in addition to marine organic matter. We conclude that the quality and quantity of organic carbon deposited to the benthos directly influence benthic biomass.
\end{abstract}

\section{INTRODUCTION}

The relationship between high abundance and biomass of benthic fauna on marine shelves and the deep sea and enhanced carbon flux to the sediments has been well documented (Zenkevitch 1963, Rowe 1971, Elmgren 1978, Smith et al. 1983, Davies \& Payne 1984, Valiela 1984). The quality and quantity of organic matter that descends to the sea floor as potential food is dependent on a variety of factors, including primary production, phytoplankton sinking rate, zooplankton grazing rate, mixed layer depth, overall water column depth and proximity to land runoff sources (Parsons et al. 1977, Pace et al. 1984, Wassman 1984). The biomass of benthic communities, therefore, reflects processes occurring in the overlying water. In addition, the benthos averages water column processes over seasonal and annual time scales, thus indicating longer-

Address for correspondence: Marine Biology Research Section, Department of Biological Sciences, University of Southern California, Los Angeles, California 90089-0371, USA term trends (Rowe 1971, Elmgren 1978, Graf et al. 1982, Jones 1984).

In this study, we used carbon/nitrogen (C/N) and stable carbon isotope $\left(\delta^{13} \mathrm{C}\right)$ ratios of particulate organic matter in surface sediments to provide an indication of the nutritional quality and source of organic matter reaching the benthos on the shelf of the northern Bering and Chukchi Seas. We hypothesized that benthic biomass was directly related to these surface sediment characteristics and hence would also reflect major differences in overlying water column production. This work was part of an interdisciplinary oceanographic study (ISHTAR: Inner Shelf Transfer and Recycling), which provided supporting data on water mass features and water column productivity.

The shallow shelf of the northern Bering and Chukchi Seas, with water depths averaging less than $50 \mathrm{~m}$, is ice covered for 7 to 8 mo during the year (Fig. 1). Northerly flowing currents transport Bering Sea water through Bering Strait and across the shelf in the Chukchi Sea. Sediments are characterized by fine and very fine sand grain size patterns in the central region of the 


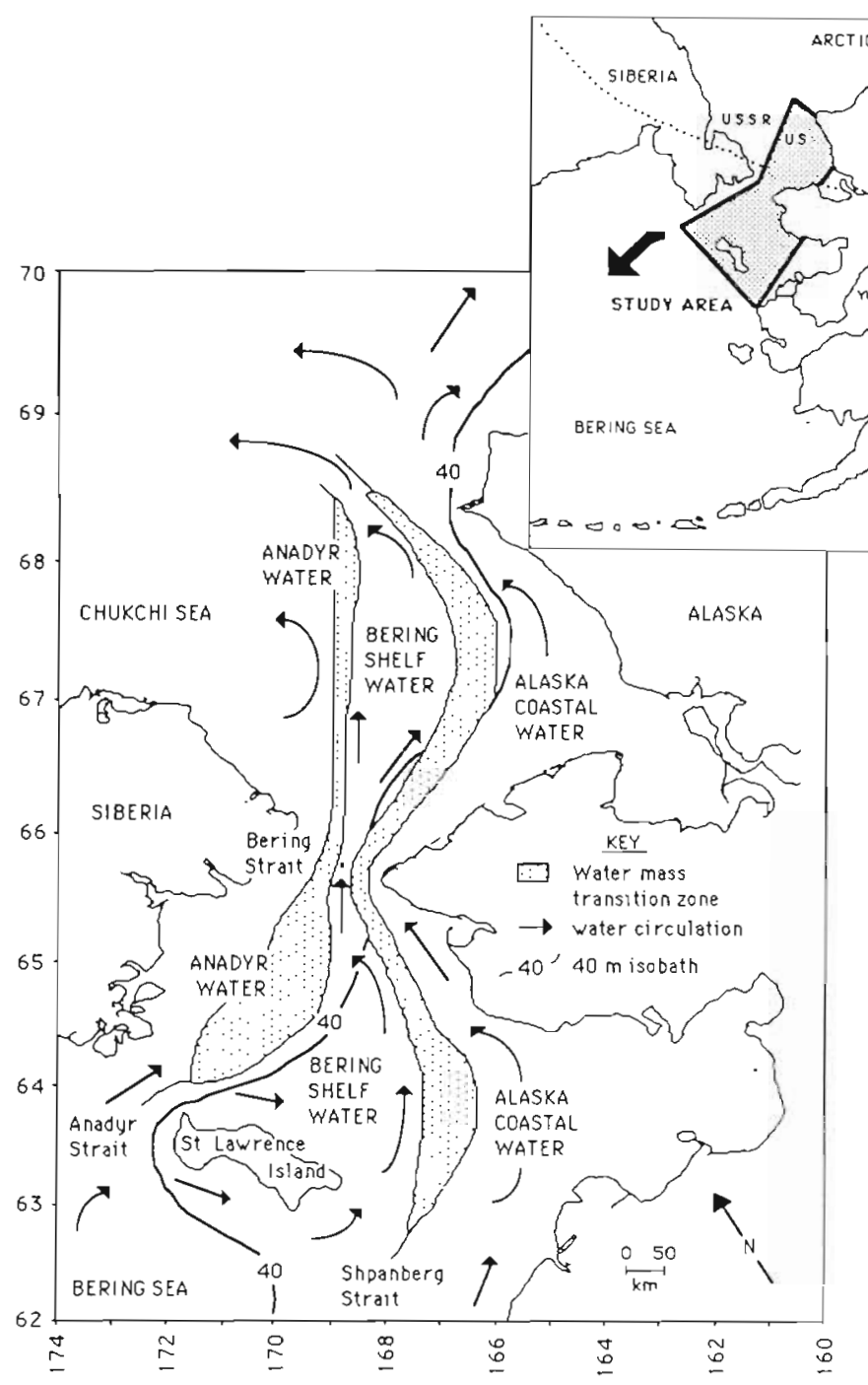

northern Bering Shelf, known as the Chirikov Basin, with coarser grained sand, pebbles and rock near the outer boundaries of this basin and in Anadyr and Bering Straits (Creager \& McManus 1967, McManus et al. 1977). A high percentage of very fine sand, silt and clay characterize the central region of the Chukchi shelf, where net accumulation of Yukon River sediment and organic particulates occurs (McManus \& Smyth 1970 McManus et al. 1974, 1977). Although data are limited the tidal range in the study area appears small, ranging from 5 to $10 \mathrm{~cm}$ (Pearson et al. 1981, Kowalik \& Matthews 1982).

The summer season physical oceanographic regime in the northern Bering and Chukchi Seas includes 3 water masses that are steered bathymetrically northward across the northern Bering Shelf into the Chukchi Sea (Coachman et al. 1975, Schumacher et al. 1983; Fig. 1). These water masses are defined by T/S profiles and were characterized during 1985 and 1986 by the
Fig. 1. Study area in the northern Bering and Chukchi Seas showing local water circulation, water masses, and bathymetry (modified from Coachman et al. 1975, Nelson et a.l. 1981, and Coachman 1987)

following bottom water properties: Anadyr Water $\left(\mathrm{S} \geq 32.5 \%, \mathrm{~T}=-1.0\right.$ to $\left.1.5^{\circ} \mathrm{C}\right)$ on the western side of the system, Bering Shelf Water ( $\mathrm{S}=31.8$ to $32.5 \%, \mathrm{~T}=$ 0 to $1.5^{\circ} \mathrm{C}$ ) in the middle region, and Alaska Coastal Water (ACW; $\mathrm{S} \leq 31.8 \%, \mathrm{~T} \geq 4{ }^{\circ} \mathrm{C}$ ) near the Alaska coast (Coachman 1987). While the Bering Shelf and Alaska Coastal waters are distinct in density and form a well-defined frontal zone, the Anadyr and Bering Shelf waters are less distinct and the interface forms a more gradual gradient from east to west. Since the salinity, temperature, and nutrient signature of this central water is a combination of both Anadyr and Bering Shelf waters, the combined water hereafter is designated as the Bering Shelf-Anadyr Water (BSAW).

High primary and secondary productivity characterize the northern Bering and Chukchi Seas in BSAW (McRoy et al. 1972, Alton 1974, Stoker 1978, 1981. Grebmeier 1987, Springer 1988, Walsh et al. 1988). BSAW has an estimated annual primary production of 250 to $300 \mathrm{~g} \mathrm{C} \mathrm{m}^{-2}$ compared to an estimated annual primary production of $50 \mathrm{~g} \mathrm{C} \mathrm{m}^{-2}$ in ACW (Sambrotto et al. 1984, Springer 1988, Walsh et al. 1988). In the literature, the largest reported benthic biomass (standing stock) on the Bering Sea shelf was found in the Chirikov Basin north of St Lawrence Island $\left(905 \mathrm{~g} \mathrm{~m}^{-2}\right.$; Alton 1974), Later studies also determined that highest Bering Sea benthic standing stocks occurred in the northern Bering Sea (482 to $631 \mathrm{~g} \mathrm{~m}^{-2}$ ) and in the Bering Strait (635 to $673 \mathrm{~g} \mathrm{~m}^{-2}$; Stoker 1978, Feder et al. 1985, Grebmeier 1987). In addition, Stoker (1978) and Grebmeier (1987) found mean benthic standing stocks to be high in the southern Chukchi Sea (465 to $591 \mathrm{~g} \mathrm{~m}^{-2}$ ). A wide range of mean benthic standing stock values ( 55 to $482 \mathrm{~g} \mathrm{~m}^{-2}$ ) occurred in regions closer to the Alaska coastline in the northern Bering and Chukchi Seas (Stoker 1978, Feder et al. 1985, Grebmeier 1987). Increasing mean benthic standing stock with latitude has been observed for the shelf of the Bering and Chukchi Seas, ranging from $3 \mathrm{~g} \mathrm{C} \mathrm{m}^{-2}$ at $60^{\circ} \mathrm{N}$ to $23 \mathrm{~g} \mathrm{C} \mathrm{m}^{-2}$ at $68^{\circ} \mathrm{N}$, although variability was 
extremely high in the northern Bering and southern Chukchi Seas. This trend was correlated with sediment grain size and temperature (Stoker 1978, 1981). Unlike our study, Stoker had limited oceanographic data, but suggested 4 factors which could influence benthic structure and biomass: primary productivity, terrestrial detritus input, current regimes, and distribution of predators.

Carbon/nitrogen ratios in surface sediments can provide an indication of the food quality of organic matter arriving at the sea bottom, although information on organic matter constituents (i.e. proteins, carbohydrates and lipids) may better differentiate the nutritional quality of organic matter in changing environmental conditions (Parsons et al. 1977, Valiela 1984). The quality of detritus available to the benthos is largely determined by source and degree of decomposition when it reaches the bottom (Tenore et al. 1982). Low C/N ratios (6 to 8 ) in surface sediments often indicate regions of high quality, recent marine phytodetritus deposition, while areas characterized by high $\mathrm{C} / \mathrm{N}$ values $(>10)$ indicate either low quality, older, more refractory detrital material or terrestrial deposits or both (Parsons et al. 1977, Walsh 1980, Valiela 1984). In the southeastern Bering Sea, variations in the cross-shelf distribution of $\mathrm{C} / \mathrm{N}$ ratios in surface sediments were attributed to different proportions of detritus (Walsh et al. 1981, Walsh \& McRoy 1986). Surface sediment $\mathrm{C} / \mathrm{N}$ ratios were low (near 6 ) in the middle shelf region, which was characterized by high pelagic primary production, low water temperatures, low pelagic grazing, high benthic biomass and high sediment oxygen consumption, indicating enhanced carbon flux to the benthos. In comparison, surface sediment $\mathrm{C} / \mathrm{N}$ ratios increased to 10 in the outer shelf sediments where pelagic grazing dominated and benthic biomass was low, suggesting carbon flux to the benthos was low and sediment organic carbon was more refractory in nature than in the middle shelf region (Iverson et al. 1979, Haflinger 1981, Walsh \& McRoy 1986)

Ecological studies using stable carbon isotopes have addressed the role of marine and terrestrial organic carbon in marine food webs (Fry \& Sherr 1984, Mills et al. 1984). Stable carbon isotope measurements provide a tracing method for ecological systems with isotopically distinct source materials. Terrestrial and marine source materials in the southeastern Bering Sea are distinct. Marine phytoplankton in the southeastern Bering Sea have an average $\delta^{13} \mathrm{C}$ value of $-24 \%$ (McConnaughey \& McRoy 1979). Average $\delta^{13} \mathrm{C}$ less than $-25 \%$ indicate carbon of terrestrial origin (Walsh et al. 1981, Fry \& Sherr 1984). The $\delta^{13} \mathrm{C}$ values of the southeastern Bering Sea shelf sediments are $-22 \%$ to $-23 \%$, indicating a marine origin (Peters et al. 1978).

Carbon isotope ratios provide information on the relative proportion of marine vs terrestrial sources in marine sediments when all causes of isotopic variability are taken into account. Sediments show a small but consistent increase in $8^{13} \mathrm{C}$ values between particulate organic carbon (POC) in the water column and in the sediments, with surface sediment organic carbon being about $2 \%$ more enriched in the heavier ${ }^{13} \mathrm{C}$ isotope than water column POC (Fry \& Sherr 1984). The influence of microbial metabolism and terrestrial carbon in the benthos complicate the differentiation between marine and terrestrial input. The use of multiple indices, such as a combination of $\delta^{13} \mathrm{C}$ values and $\mathrm{C} / \mathrm{N}$ ratios, help distinguish sources of organic carbon in sediments.

\section{MATERIAL AND METHODS}

Bottom samples for sediment analyses were collected using a Haps corer or a MK3 box corer. Sediment subsamples were taken with either 6 or $13 \mathrm{~cm}$ diameter plexiglas cores, $26 \mathrm{~cm}$ long, and frozen for later laboratory analysis. Surface sediments ( $1 \mathrm{~g})$ were analysed for $\mathrm{C} / \mathrm{N}$ ratios (weight/weight) by acidification with $2 \mathrm{ml}$ of $1 \mathrm{NHCl}$ and dried at $105^{\circ} \mathrm{C}$ overnight to obtain carbonate-free sediments, and then homogenized. Duplicate carbon and nitrogen content measurements were determined on a Perkin-Elmer Model 240C CHN elemental analyser.

Sediments for stable carbon isotope analysis were processed following the methodology of Dunton \& Schell (1987) and analysed on a VG Instruments Sira-9 mass spectrometer. The $\delta^{13} \mathrm{C}(\%)$ values reported are relative to the Peedee Belemnite (PDB) standard (Craig 1953), with 2 internal standards used to calibrate the mass spectrometer. Precision relative to the standard was $\pm 0.2 \%$. $\delta^{13} \mathrm{C}$ is a means of expressing carbon isotope ratios where:

$$
\delta{ }^{13} \mathrm{C}=\left\{\left[\left({ }^{13} \mathrm{C} /{ }^{12} \mathrm{C}_{\text {sample }}\right) /\left({ }^{13} \mathrm{C} /{ }^{12} \mathrm{C}_{\text {standard }}\right)\right]-1\right\} \times 10^{3} .
$$

More negative values indicate material relatively depleted in the ${ }^{13} \mathrm{C}$ isotope.

Benthic communities were sampled by collecting 4 replicate $0.1 \mathrm{~m}^{2}$ van Veen grabs (with penetration enhanced by $32 \mathrm{~kg}$ ) at each station. Each sample was washed through $1 \mathrm{~mm}$ screens and animals subsequently preserved in $10 \%$ hexamethyltetraminebuffered formalin, stored in plastic Whirl-pak bags, and saved for laboratory analysis. Animals were keyed to family level, blotted dry, then weighed to determine wet-weight biomass. Wet-weights were converted to organic carbon biomass using previously verified conversion values (Stoker 1978). The carbon conversions enable comparison of biomass between stations by reducing the influence of the calcium carbonate tests of 
mollusks and echinoids on total biomass. Stoker determined carbon conversion values for dominant faunal species or lowest determined taxa level; his values were used either as single or averaged numbers for individual faunal families in the present study.

Salinity, temperature, and depth data were collected in conjunction with other investigators using a Neil Brown conductivity-temperature-depth profiler. Data collected as part of the ISHTAR project, including hydrographic, nutrient and chlorophyll a data, are available from ISHTAR data reports (McRoy \& Tripp 1986, 1987) and annual progress reports.

Correlations between station variables and sediment and benthic biomass parameters were investigated using both parametric (Pearson product-moment $r$ ) and nonparametric (Spearman's rho) correlation tests. Parametric tests were utilized when a large enough sample size was available to assume a normal distribution. The nonparametric Kruskal-Wallis test was used to investigate between-year differences in benthic biomass and sediment $\mathrm{C} / \mathrm{N}$ ratios for stations located within either BSAW or ACW. The nonparametric Mann-Whitney $U$ test was used to test whether there was a significant difference in mean benthic biomass values between stations located in BSAW and ACW. A statistical package was utilized (StatView, BrainPower 1985) and test statistics were evaluated using standard tables (Rohlf \& Sokal 1969, Conover 1980).

Each station designation presented in subsequent tables is composed of 5 numbers: the first 2 numbers designate the sequential cruise number and the last 3 numbers designate the station.

\section{RESULTS}

Eighty-eight stations were occupied over 3 field seasons during July to September from 1984 to 1986 using the RV 'Alpha Helix' (Fig. 2). Cruise dates were 30 June to 10 July 1984 (Cruise 59), 25 July to 10 August 1985 (Cruise 73), 26 August to 9 September 1985 (Cruise 74), 11 to 26 July 1986 (Cruise 85) and 14 to 24 August 1986 (Cruise 87). Only summary maps of sediment data will be presented in this paper, with individual station hydrographic and sediment values available in Grebmeier (1987) or upon request from the senjor author. Benthic biomass and dominant fauna were determined at 49 of the 88 stations (Table 1) Results of the statistical analysis comparing the 2 measurements of biomass showed a significant correlation between wet-weight biomass and organic carbon biomass ( $r=0.617, p<0.005, n=49$ ). If the 5 stations (59071, 59132, 59134, 59150 and 74057) where echinoids dominate are deleted (Grebmeier 1987), $r$ increases to $0.948, p<0.005$, indicating a very strong

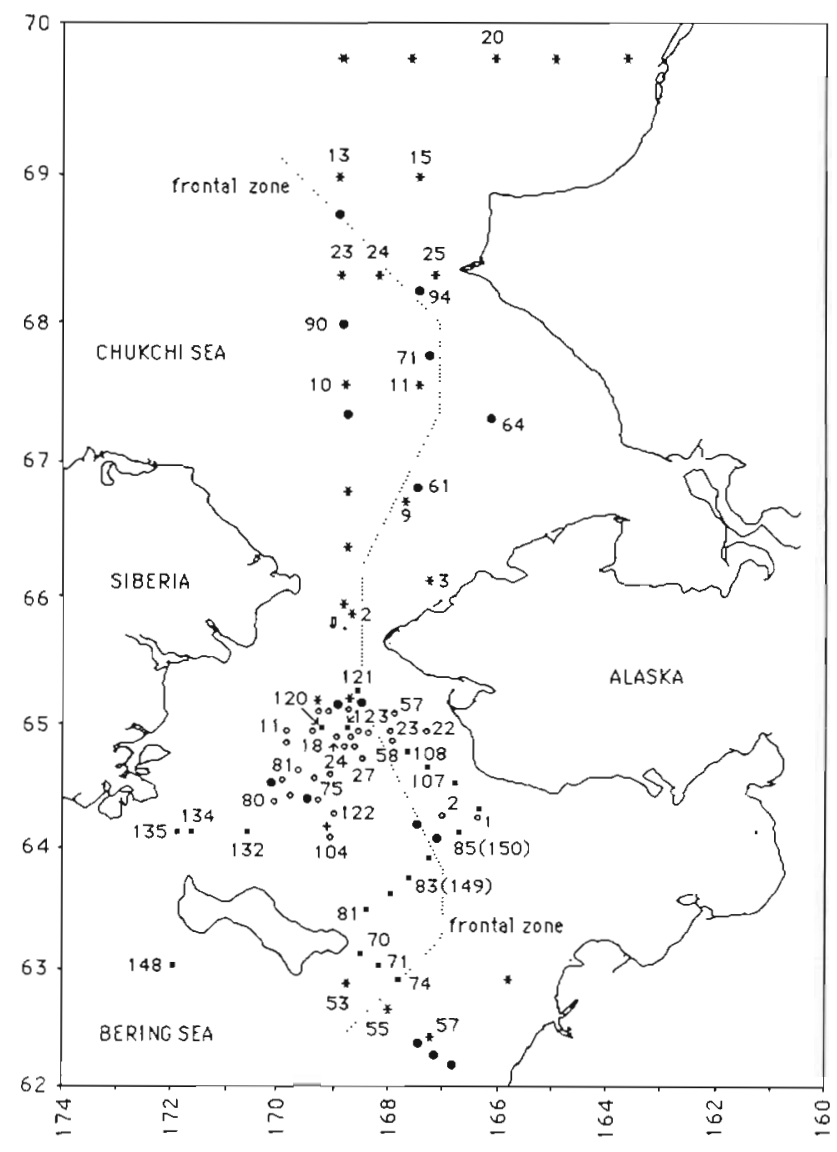

Fig. 2. Location of stations in the northern Bering and Chukchi Seas for RV 'Alpha Helix' Cruises $59(\bullet), 73(0), 74(*), 85$ (•), and $87(+)$. Only stations where benthic fauna were collected are numbered. A frontal zone separates Bering Shelf-Anadyr Water in the west from Alaska Coastal Water in the east

correlation between preserved wet-weight and organic carbon weight.

The temperature and salinity data confirmed the presence of the front dividing BSAW and ACW This front, which varies in location over the open-water season, separates BSAW and ACW with a salinity boundary of $31.8 \%$ (Coachman 1987). The average location of the front was used to designate station locations relative to BSAW and ACW (Fig. 2).

\section{Carbon/nitrogen ratios in surface sediments}

Carbon/nitrogen ratios in the surface sediments were lowest (mean $=6$ to 7 ) in the central regions of the northern Bering and southern Chukchi Sea shelves, indicating labile phytodetrital material (Fig. 3). Higher ratios (mean $\geq 8.0$ ), indicating refractory and/or terrestrial carbon sources mixed with phytodetritus, occurred adjacent to the Alaska coastline. There was no significant difference between years of mean $\mathrm{C} / \mathrm{N}$ 
Table 1. Summary of benthic biomass and dominant fauna (ranked by biomass) at all stations for Cruises 59, 73, 74 and 85

\begin{tabular}{|c|c|c|c|}
\hline Station & Biomass $\left(\mathrm{g} \mathrm{m}^{-2}\right)$ & Biomass $\left(\mathrm{g} \mathrm{C} \mathrm{m}^{-2}\right.$ ) & Dominant fauna (ranked by biomass) \\
\hline 59070 & 549.6 & 22.9 & Tunicates, polychaetes \\
\hline 59071 & 2143.8 & 18.6 & Sand dollars, bryozoans, polychaetes \\
\hline 59074 & 42.0 & 2.6 & Polychaetes \\
\hline 59081 & 388.8 & 13.7 & Bivalves, sea anenomes \\
\hline 59107 & 35.3 & 2.0 & Amphipods, sipunculids \\
\hline 59108 & 108.6 & 3.0 & Bivalves, polychaetes \\
\hline 59120 & 725.4 & 32.2 & Amphipods, bivalves \\
\hline 59121 & 739.5 & 29.5 & Amphipods, bivalves \\
\hline 59123 & 685.5 & 26.8 & Amphipods, bivalves \\
\hline 59132 & 2377.0 & 20.9 & Sand dollars, sea urchins, bivalves \\
\hline 59134 & 744.8 & 11.3 & Sea urchins, bivalves, sea anenomes \\
\hline 59135 & 517.5 & 13.7 & Sea anenomes, polychaetes, sea urchins \\
\hline 59148 & 405.1 & 13.3 & Bivalves, polychaetes, amphipods \\
\hline 59149 & 180.0 & 9.0 & Amphipods, polychaetes, sipunculids \\
\hline 59150 & 699.3 & 10.4 & Sand dollars, polychaetes, bivalves \\
\hline 73001 & 257.4 & 7.4 & Polychaetes, sea cucumbers, tunicates \\
\hline 73002 & 291.0 & 8.5 & Bivalves, tunicates, polychaetes \\
\hline 73011 & 405.2 & 19.7 & Amphipods, bivalves, polychaetes \\
\hline 73018 & 520.2 & 21.3 & Amphipods, bivalves \\
\hline 73022 & 39.0 & 1.8 & Polychaetes, amphipods \\
\hline 73023 & 894.4 & 22.3 & Tunicates, bivalves, polychaetes \\
\hline 73024 & 706.7 & 25.9 & Amphipods, bryozoans, bivalves \\
\hline 73027 & 289.3 & 12.8 & Amphipods, bryozoans, bivalves \\
\hline 73057 & 17.6 & 1.0 & Polychaetes, bivalves \\
\hline 73058 & 97.2 & 2.9 & Amphipods, polychaetes, sand dollars \\
\hline 73075 & 505.9 & 24.5 & Amphipods, bivalves \\
\hline 73080 & 493.1 & 17.7 & Bivalves \\
\hline 73081 & 308.2 & 17.4 & Amphipods, bivalves \\
\hline 73104 & 342.2 & 20.1 & Amphipods, bivalves \\
\hline 73122 & 242.0 & 14.0 & Amphipods, bivalves \\
\hline 74002 & 318.9 & 11.6 & Bivalves, polychaetes \\
\hline 74003 & 86.3 & 3.2 & Bivalves, polychaetes, bryozoans \\
\hline 74009 & 196.5 & 4.6 & Bivalves, tunicates \\
\hline 74010 & 1593.2 & 59.0 & Bivalves, amphipods \\
\hline 74011 & 330.8 & 15.1 & Bivalves, polychaetes \\
\hline 74013 & 51.7 & 1.3 & Brittle stars, bivalves \\
\hline 74015 & 29.7 & 1.7 & Polychaetes, gastropods \\
\hline 74020 & 17.0 & 9.9 & Sipunculids, polychaetes \\
\hline 74023 & 484.3 & 20.1 & Bivalves, polychaetes, sea anenomes \\
\hline 74024 & 190.1 & 7.9 & Bivalves, polychaetes \\
\hline 74025 & 71.3 & 3.9 & Bivalves, sea anenomes, polychaetes \\
\hline 74053 & 485.5 & 16.7 & Bivalves, polychaetes \\
\hline 74055 & 160.9 & 4.5 & Bivalves, amphipods, sand dollars \\
\hline 74057 & 883.8 & 8.3 & Sand dollars, bivalves, polychaetes \\
\hline 85061 & 412.0 & 7.4 & Tunicates, bivalves, polychaetes \\
\hline 85064 & 35.0 & 1.7 & Polychaetes, bivalves \\
\hline 85071 & 118.0 & 8.5 & Polychaetes \\
\hline 85090 & 629.6 & 32.4 & Bivalves, polychaetes, sea anenomes \\
\hline 85094 & 423.3 & 19.2 & Polychaetes, sipunculids \\
\hline
\end{tabular}

ratios in surface sediments underlying BSAW (KruskalWallis, $p>0.25$; Table 2) However, a significant difference in $\mathrm{C} / \mathrm{N}$ ratios was found between years for surface sediments underlying ACW (Kruskal-Wallis, $0.025<p<0.05$; Table 2). Lower surface sediment $\mathrm{C} / \mathrm{N}$ ratios were correlated with increased water column depth $(r=-0.361, p<0.01, n=78)$.

\section{Stable carbon isotope ratios $\left(\delta^{13} \mathrm{C}\right)$}

Surface sediments from 19 stations were analysed for stable carbon isotope ratios (Fig. 4). Generally, more negative values occurred in ACW off the Yukon River $(-23.5 \%)$ and in the northern part of the Chukchi Sea $(-23.4 \%$ and $-23.8 \%)$. The least negative values 


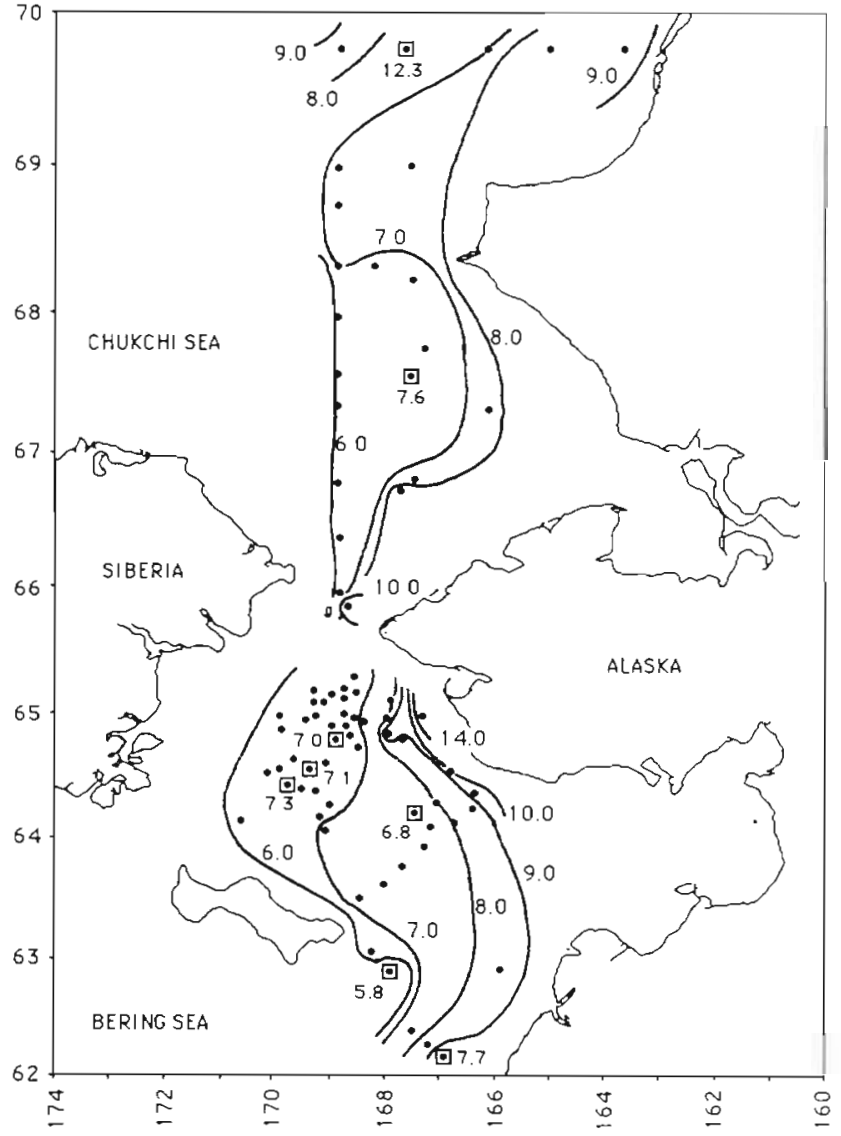

Fig. 3. Distribution of $\mathrm{C} / \mathrm{N}$ ratios in surface sediments in the northern Bering and Chukchi Seas. Stations with $\mathrm{C} / \mathrm{N}$ ratios outside of contour intervals are boxed and individual values presented

$(-21.0 \%$ to $-21.3 \%)$ typically occurred under BSAW in the northern Bering and southern Chukchi Seas.

A nonparametric Spearman rank correlation test was performed to test the hypothesis that $0^{13} \mathrm{C}$ ratios become more negative with increasing $\mathrm{C} / \mathrm{N}$ ratios in sediments, suggesting more terrestrial carbon input and more detrital processing in these sediments. Although a relationship was found between more negative ${ }^{13} \mathrm{C}$ values and higher $\mathrm{C} / \mathrm{N}$ ratios, this relationship was only marginally significant, based on a 1 -

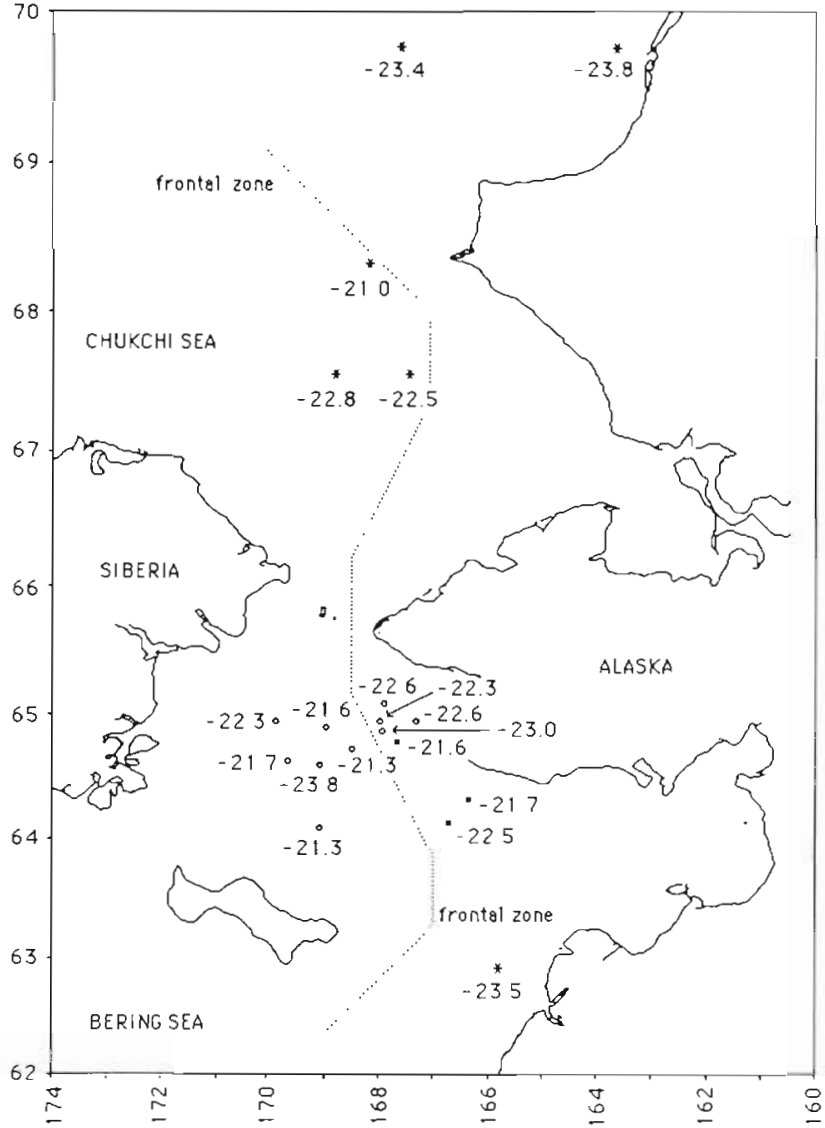

Fig. 4. Distribution of $\delta^{13} \mathrm{C}$ ratios in surface sediments for Cruises 59 (घ), 73 (), and 74 (*) in the northern Bering and Chukchi Seas in relation to the BSAW-ACW frontal zone

tailed test (Spearman's rho $=-0.345,0.05<p<0.10$ $n=19$ )

\section{Total organic carbon in surface sediments}

The distribution of total organic carbon (TOC) in surface sediments was lowest (mean $=0.5 \%$ ) in the northern Bering Sea and highest (mean $=1.5 \%$ ) in the Chukchi Sea (Fig. 5). The highest sediment organic

Table 2. Mean surface sediment C/N ratios from 1984 to 1.986 for stations located in Bering Shelf-Anadyr Water and Alaska Coastal Water (including number of stations in parentheses and standard deviation, SD)

\begin{tabular}{|cccc|}
\hline Year & \multicolumn{2}{c}{$\begin{array}{c}\text { Bering Shelf-Anadyr Water } \\
\text { Mean surface sediment }\end{array}$} & SD \\
C/N ratios & & Alaska Coastal Water \\
\hline 1984 & $7.02(9)$ & 0.52 & Mean surface sediment \\
C/N ratios
\end{tabular}




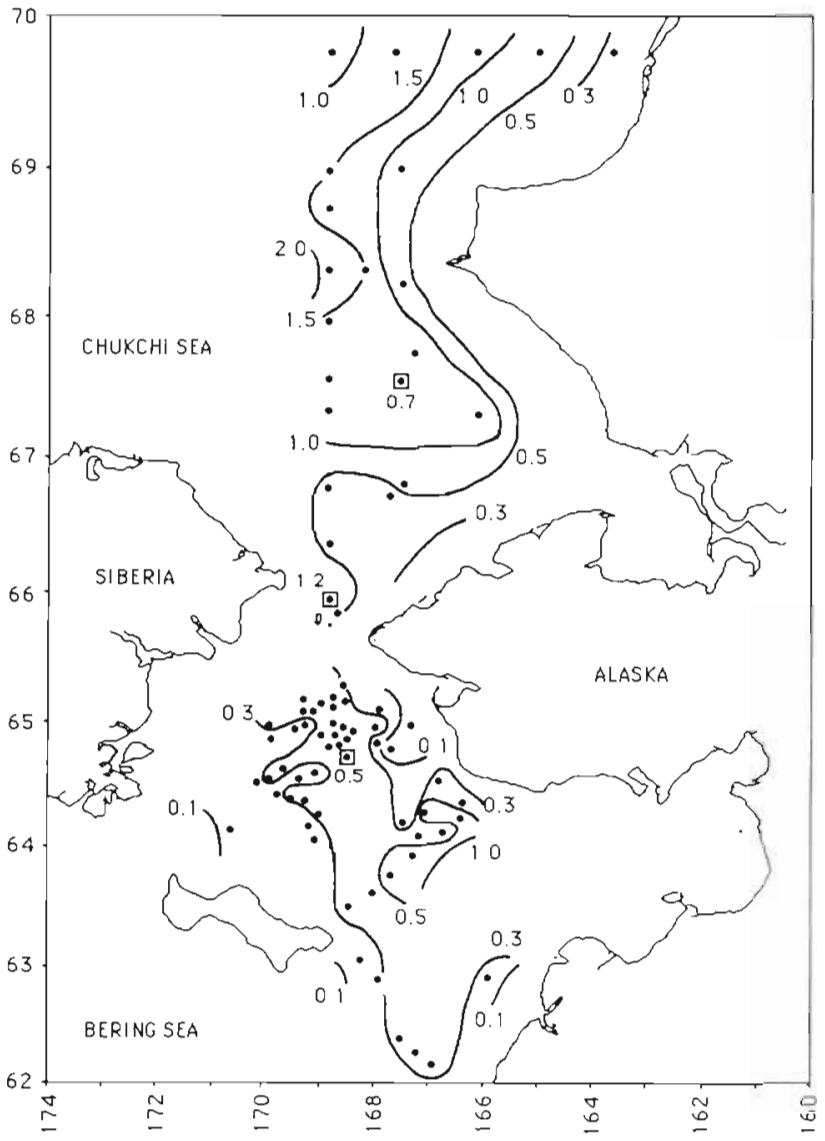

Fig. 5. Distribution of total organic carbon (\%) in surface sediments in the northern Bering and Chukchi Seas

carbon content was bimodal with peaks occurring in the northern Bering and Chukchi Seas. Maximum organic carbon accumulation apparently occurs in the central region of the Chukchi Sea, where it is $1.9 \%$.

\section{Benthic biomass}

Mean benthic biomass was 3- to 4-fold higher for stations in BSAW compared to those in $\mathrm{ACW}$ in both the northern Bering and Chukchi Seas (Fig. 6). Mean benthic biomass did not vary significantly between

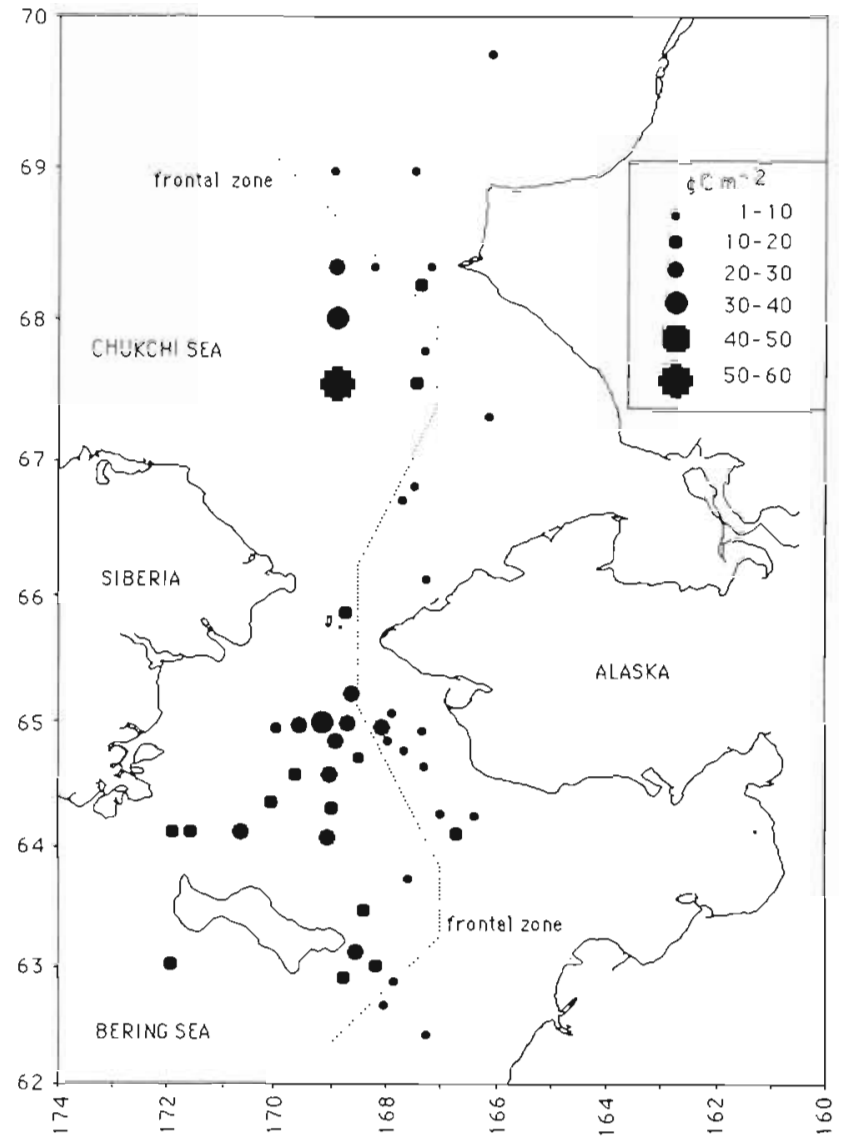

Fig. 6. Distribution of benthic biomass in the northern Bering and Chukchi Seas in relation to the BSAW-ACW frontal zone

years (1984 to 1986) by location within either BSAW or ACW (Table 3; Kruskal-Wallis test, $p>0.25$ ), thus values were pooled to compare means between BSAW and ACW for all stations. Biomass averaged $20.2 \mathrm{~g} \mathrm{C}$ $\mathrm{m}^{-2}$ in BSAW and decreased to $6.3 \mathrm{~g} \mathrm{C} \mathrm{m}^{-2}$ in ACW (Table 4). The difference in mean benthic biomass between BSAW and ACW was significant (Mann-Whitney $U$ test, $p<0.0001)$.

Mean benthic biomass was significantly correlated to 4 environmental parameters: water column integrated and bottom chlorophyll a values, surface sediment $\mathrm{C} / \mathrm{N}$ ratios, and water column depth (Table 5).

Table 3. Mean benthic biomass from 1984 to 1986 for stations located in Bering Shelf-Anadyr Water (including number of stations in parentheses and standard deviation, SD)

\begin{tabular}{|c|c|c|c|c|}
\hline \multirow[t]{2}{*}{ Year } & \multicolumn{2}{|c|}{ Bering Shelf-Anadyr Water } & \multicolumn{2}{|c|}{ Alaska Coastal Water } \\
\hline & $\begin{array}{l}\text { Mean benthic biomas } \\
\qquad\left(\mathrm{g} C \mathrm{~m}^{-2}\right)\end{array}$ & $\mathrm{SD}$ & $\begin{array}{l}\text { Mean benthic biomass } \\
\qquad\left(\mathrm{g} C \mathrm{~m}^{-2}\right)\end{array}$ & $\mathrm{SD}$ \\
\hline 1984 & $19.3(11)$ & 7.8 & $4.5(4)$ & 3.8 \\
\hline 1985 & 20.9 (14) & 11.9 & $6.2(15)$ & 5.6 \\
\hline 1986 & $20.4(2)$ & 16.9 & $9.4(3)$ & 8.9 \\
\hline
\end{tabular}


Table 4. Comparison of mean biomass of benthic fauna for stations located in Bering Shelf-Anadyr Water and Alaska Coastal Water in the northern Bering and Chukchi Seas (including number of stations in parentheses and standard deviation, SD)

\begin{tabular}{|c|c|c|c|c|}
\hline \multirow[t]{2}{*}{ Location } & \multicolumn{2}{|c|}{ Bering Shelf-Anadyr Water } & \multicolumn{2}{|c|}{ Alaska Coastal Water } \\
\hline & $\begin{array}{l}\text { Mean benthic biomass } \\
\left(\mathrm{g} \mathrm{C} \mathrm{m}^{-2}\right)\end{array}$ & $\mathrm{SD}$ & $\begin{array}{l}\text { Mean benthic biomass } \\
\qquad\left(\mathrm{g} \mathrm{C} \mathrm{m}^{-2}\right)\end{array}$ & $\mathrm{SD}$ \\
\hline Northern Bering Sea & $19.1(2.1)$ & 6.2 & $6.2(12)$ & 6.0 \\
\hline Chukchi Sea & $23.8(6)$ & 19.4 & $6.5(10)$ & 5.7 \\
\hline All stations & $20.2(27)$ & 10.3 & $6.3(22)$ & 5.7 \\
\hline
\end{tabular}

Table 5. Pearson product-moment correlation statistics between benthic biomass and environmental parameters

\begin{tabular}{|c|c|c|}
\hline \multirow{2}{*}{$\begin{array}{l}\text { Environmental parameter } \\
\text { (no. of observations) }\end{array}$} & \multicolumn{2}{|c|}{ Benthic biomass } \\
\hline & $\begin{array}{l}\text { Correlation } \\
\text { coefficient } \\
\quad r\end{array}$ & $\begin{array}{l}\text { Level of } \\
\text { significance } \\
\qquad p\end{array}$ \\
\hline Integrated chlorophyll $a^{a}$ (34) & 0.691 & $<0.01$ \\
\hline Bottom chlorophyll $a^{\alpha}(47)$ & 0.505 & $<0.01$ \\
\hline Surface sediment $\mathrm{C} / \mathrm{N}$ ratio $(38)$ & -0.433 & $<0.01$ \\
\hline Water column depth (49) & 0.424 & $<0.01$ \\
\hline \multicolumn{3}{|c|}{$\begin{array}{l}\text { Integrated and bottom chlorophyll a values in the water } \\
\text { column are from McRoy \& Tripp }(1986,1987) \text { and Greb- } \\
\text { meier (1987) }\end{array}$} \\
\hline
\end{tabular}

A significant relation is indicated between the quality of organic matter in the sediments, characterized by $\mathrm{C} / \mathrm{N}$ ratios, and benthic biomass (Fig. 7), based on a Spearman's rho test, stated as a 1-tailed test: benthic biomass is higher at stations where surface sediment $\mathrm{C} / \mathrm{N}$ ratios are lower.

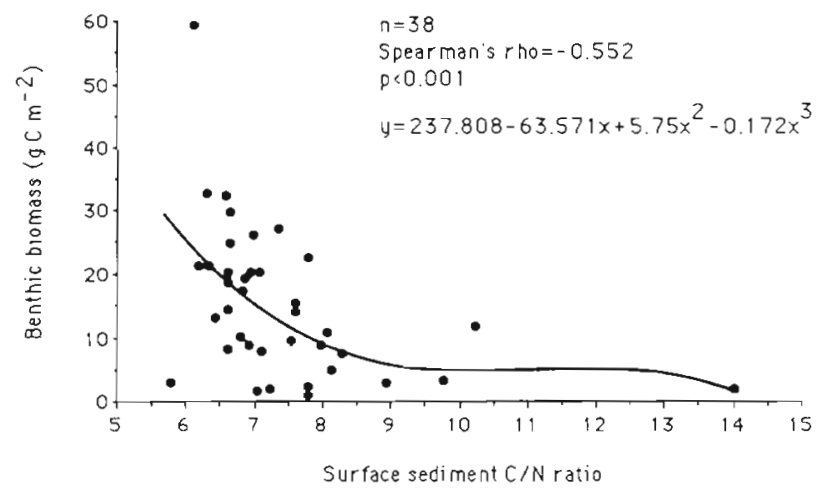

Fig. 7. Relation between surface sediment $\mathrm{C} / \mathrm{N}$ ratio and benthic biomass

\section{DISCUSSION}

If food supply is a major regulating mechanism controlling benthic biomass, then both the quality and quantity of available organic matter should be impor- tant. Estimates of bacterial and microheterotrophic grazing rates are lower ( 1 to $2 \%$ ) in BSAW than in $\mathrm{ACW}$ (50\%; Andersen \& Fenchel 1986). This is consistent with indications that little remineralization occurs of descending POC in BSAW (Grebmeier 1987). In addition, model estimates of zooplankton grazing rates on phytoplankton are relatively low (about $20 \%$ in BSAW and $16 \%$ in ACW Cooney 1981, Walsh et al. 1988). The combined estimates of bacterial, microheterotrophic and zooplankton grazing rates and measured primary production in each water type indicate that a larger food supply would reach the benthos in the highly productive BSAW than in the less productive ACW.

The sediments, in turn, reflect processes occurring in the overlying water column. Low $\mathrm{C} / \mathrm{N}$ ratios of surface sediments in BSAW indicate that a high quality, nitrogen-rich food reaches the benthos, supporting a direct coupling between water column primary production and the benthos. By comparison, high $\mathrm{C} / \mathrm{N}$ ratios of surface sediments in $\mathrm{ACW}$ indicate nitrogen-depletion and lower food quality. Inorganic nutrient supply to the euphotic zone is higher in BSAW compared to ACW (Whitledge 1986), and this may serve as one of the physical mechanisms decreasing $\mathrm{C} / \mathrm{N}$ ratios in BSAW. Phytoplankton blooms occur continuously throughout the summer in BSAW (Springer 1988), resulting in a more consistent supply of high quality phytodetritus than in ACW. Further, the low C/N ratios in BSAW sediments did not vary significantly between years over 3 field seasons. Stable carbon isotope data show a clear relationship between less negative $0^{13} \mathrm{C}$ values and low $\mathrm{C} / \mathrm{N}$ ratios in surface sediments of the northern. Bering and Chukchi Seas, supporting a marine origin for this detritus (Parker \& Scalan 1987). Our sediment carbon isotope data also suggests a similar relationship to $\mathrm{C} / \mathrm{N}$ ratios, but the correlation was only marginally significant, probably due to low sample size relative to that of Parker \& Scalan's work.

In contrast to BSAW, high $\mathrm{C} / \mathrm{N}$ ratios $(8.0$ to 14.0 ) occurred in surface sediments near the Alaska coastline, indicating increased input of lower quality refractory and terrestrial organic matter. Average C/N ratios for suspended material in the upper Yukon River are 
14.5, decreasing to 10.5 at the mouth (Feeley et al. 1981). Most of the Yukon River suspended load remains in $\mathrm{ACW}$, with primary deposition sites occurring in Norton Sound (just north of the Yukon River) and downstream in the Chukchi Sea (McManus \& Smyth 1970, McManus et al. 1977). Unlike sediment underlying BSAW, there is a significant difference in surface sediment $\mathrm{C} / \mathrm{N}$ ratios interannually in $\mathrm{ACW}$. This might be a result of the interannual variability in maximum water runoff and suspended particulate load measured in the Yukon River (US Geological Survey 1986). Both our findings and those of Parker \& Scalan (1987) suggest a relationship between more negative $\delta^{13} \mathrm{C}$ values and higher $\mathrm{C} / \mathrm{N}$ ratios in surface sediments, indicating a riverine influence.

Water column primary production was 5 to 6 times greater in BSAW than in ACW (Springer 1988). There was a corresponding 3- to 4 -fold greater mean benthic biomass in BSAW than in ACW in both the northern Bering and Chukchi Seas. This supports the hypothesis that there is a coupling between water column and benthic production. In addition, total sediment oxygen uptake rates in the northern Bering and Chukchi Seas are 2 to 3 times greater in BSAW sediments than in ACW sediments (Grebmeier 1987). Assuming a relationship between organic matter supply rate and sediment oxygen uptake rates, these data indicate that organic matter supplied to the benthos is at least 2 to 3 times higher in BSAW compared to ACW. Furthermore, the highest integrated chlorophyll a values (1985 and 1986) occurred in BSAW in both the northern Bering and Chukchi Seas (Fig. 8; Grebmeier 1987, Springer 1988). A significant positive correlation occurred between integrated chlorophyll $a$ and benthic biomass (Table 5). The correlation exists despite the obvious problems in comparing phytoplankton biomass with benthic biomass that reflect long-term food supply patterns.

Benthic biomass was also positively correlated with water column depth. Shallower sites $(<20 \mathrm{~m})$ can be scoured by winter ice and currents (Nelson et al. 1981), which could reduce the amount of food reaching the benthos as well as physically disturb the bottom, resulting in lower benthic biomass. However, the range of depths is similar for our stations in both BSAW (20 to 55 $\mathrm{m}$ ) and $\mathrm{ACW}$ (19 to $51 \mathrm{~m}$ ), yet the range of benthic biomass is greater in BSAW ( 7.9 to $59.0 \mathrm{~g} \mathrm{C} \mathrm{m}^{-2}$ ) than in ACW (1.0 to $22.3 \mathrm{~g} \mathrm{C} \mathrm{m}^{-2}$ ). For example, the shallowest station in BSAW (59071, depth $=20 \mathrm{~m}$ ) had a biomass of $18.6 \mathrm{~g} \mathrm{C} \mathrm{m}^{-2}$ while the shallowest station in ACW (59074, depth $=19 \mathrm{~m})$ had a biomass of only $2.6 \mathrm{~g} \mathrm{C} \mathrm{m}^{-2}$. Water column depth was also correlated positively with integrated and bottom chlorophyll a (highest values in BSAW) and negatively with surface sediment $\mathrm{C} / \mathrm{N}$ ratios (lowest values in BSAW; Grebmeier 1987). We

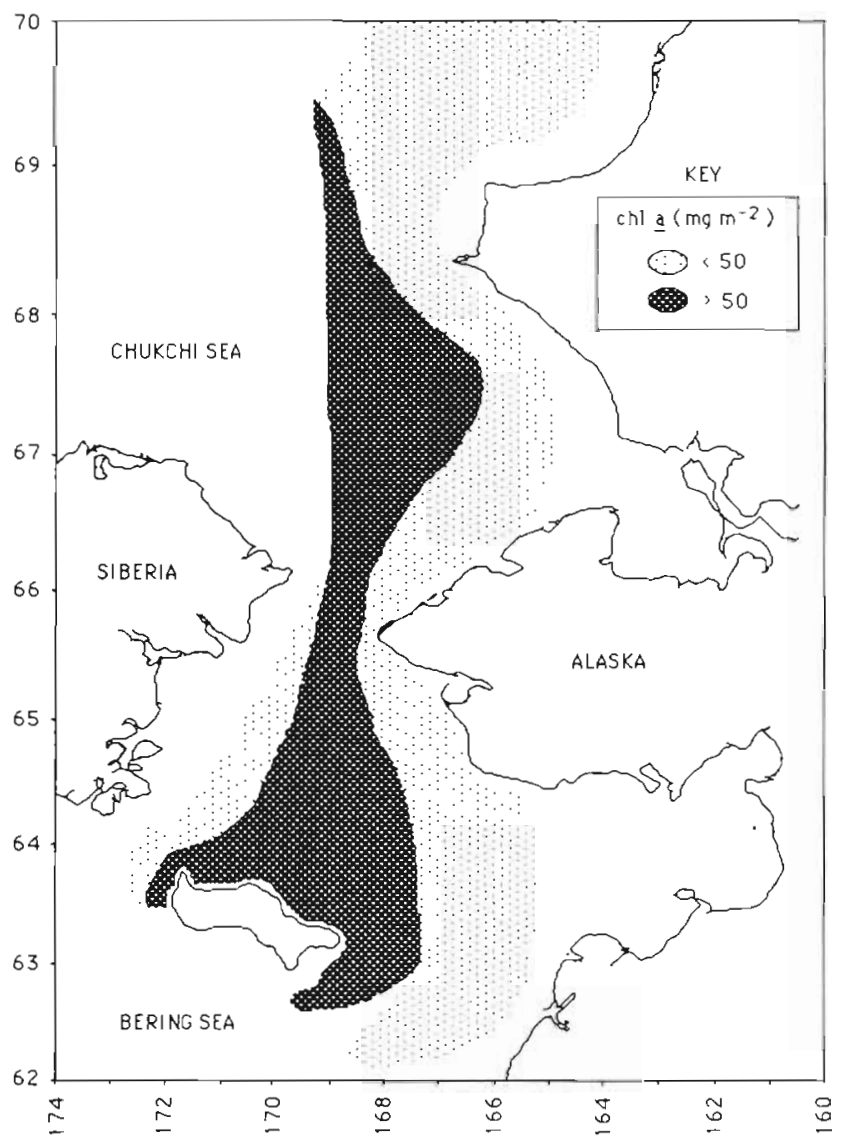

Fig. 8. Distribution of integrated chlorophyll a (chl a) during July through September 1985 and 1986 in the northern Bering and Chukchi Seas (adapted from Grebmeier 1987 and Springer 1988)

propose that the correlation of water column depth to benthic biomass is secondary in importance to the correlations of the quality and quantity of available food supply in regulating benthic biomass.

Phytoplankton and marine algal detritus, unlike vascular plant material, can be readily assimilated by some detritivores (Findlay \& Tenore 1982, Tenore et al. 1982) and there is an energetic advantage for fauna that can use high quality food sources, such as algal cells, without bacterial modification (Blackburn 1987, Tenore 1987). Studies by Blackburn (1987) indicated that the dominant macrofauna in high biomass regions of BSAW (primarily ampeliscid amphipods and tellinid and nuculid bivalves) obtained a major portion of their food directly from phytoplankton descending to the sea floor. He found that up to $70 \%$ of the sediment respiration in high amphipod and bivalve regions in BSAW was due to benthic macrofauna compared to $20 \%$ being due to macrofauna in low benthic biomass regions, such as in $\mathrm{ACW}$

In summary, benthic biomass on the shelf of the northern Bering and Chukchi Seas was directly corre- 
lated to differences observed in the quality and quantity of organic carbon reaching the sediments. Higher quality marine organic matter was available annually to benthic populations in BSAW than to those in ACW where organic matter was a lower quality as a result of variable terrestrial organic matter additions. Water column depth correlated not only with benthic biomass but also sediment $\mathrm{C} / \mathrm{N}$ ratios and water column integrated and bottom chlorophyll $a$, suggesting that its correlation with benthic biomass is more indicative of water column influences in total than as an individual factor. Mean benthic biomass was significantly higher for stations in BSAW $\left(20 \mathrm{~g} \mathrm{C} \mathrm{m}^{-2}\right)$ compared to stations in ACW ( $6 \mathrm{~g} \mathrm{C} \mathrm{m}^{-2}$ ), but there was no significant difference in biomass between years for stations within each water type. The high benthic biomass in BSAW in both the northern Bering and Chukchi Seas reflects the higher primary production and phytoplankton biomass in the overlying water column. The lack of high summer primary production and phytoplankton biomass in the nutrient-depleted ACW, coupled with low benthic biomass, suggest that a reduced food supply limits benthic biomass. The study supports the conclusion that food supply is a major regulating factor in benthic biomass in this polar region.

Acknowledgements. We thank the following people for assistance and suggestions over the study period: S. Henrichs (CHN analyses), L. Cooper (stable carbon isotope analyses), C. Chu (data analyses), and J Niebauer and E. Murphy for comments. Three anonymous reviewers provided timely and valuable comments. Logistical and financial support were provided by the ISHTAR project (NSF-DPP 84-05286), and by the University of Alaska Fairbanks through the Institute of Marine Science, the Vice-Chancellor for Research and Advanced Study and the Department of Marine Science and Limnology. Additional shiptime was generously provided by Dr George L. Hunt, Jr, University of California, Irvine. We also extend our appreciation to the Captain and crew of the RV 'Alpha Helix' for their assistance.

\section{LITERATURE CITED}

Alton, M. S. (1974). Bering Sea benthos as a food resource for dermersal fish populations. In: Hood, D. W., Kelly, E. J. (eds.) Oceanography of the Bering Sea. Inst. Mar Sci., Univ. Alaska, Fairbanks, p. 257-277

Andersen, P., Fenchel, T (1986), Pelagic bacteria and protozoa. In: Component $C$. Organic matter production and degradation on the shelf of the North Bering/Chukchi Shelves. ISHTAR 1985 Progress Report, Vol. I. Inst. Mar. Sci., Univ. Alaska, Fairbanks, p. 190-202

Blackburn, T. H. (1987). Microbial food webs in sediments. In: Sleigh, M. A. (ed.) Microbes in the seas. Ellis Horwood, Chichester, p. 39-58

BrainPower, Inc. (1985). StatView TM The graphics statistics utility for the MacIntosh ${ }^{\mathrm{TM}}$. Calabasas, California

Coachman, L. K. (1987) Advection and mixing on the BeringChukchi Shelves. Component A. Advection and mixing of coastal water on high latitude shelves. ISHTAR 1986 Prog- ress Report, Vol. I. Inst. Mar. Sci, Univ. Alaska, Fairbanks, p. $1-42$

Coachman, L. K., Aagaard, K., Tripp, R. B. (1975). Bering Strait: the regional oceanography. Univ. Wash. Press, Seattle

Conover, W. J. (1980). Practical nonparametric statistics. John Wiley and Sons, New York

Cooney, R. T (1981). Bering Sea zooplankton and micronekton communities with emphasis on annual production. In: Hood, D. W., Calder, J. A. (eds.) The eastern Bering Sea shelf: oceanography and resources, Vol. 2. Univ. Wash. Press, Seattle, p. 947-974

Craig, H. (1953). The geochemistry of the stable carbon isotopes. Geochim. Cosmochim. Acta 3: 53-92

Creager, J. S., McManus, D. A. (1967). Geology of the floor of Bering and Chukchi Seas - American studies. In: Hopkins, D. M. (ed.) The Bering land bridge. Stanford University Press, Stanford, p. 7-31

Davies, J. M., Payne, P. (1984). Supply of organic matter to the sediment in the northern North Sea during a spring phytoplankton bloom. Mar. Biol. 78: 315-324

Dunton, K. H., Schell, D. M. (1987). Dependence of consumers on macroalgal (Laminaria solidungula) carbon in an arctic kelp community: $\delta^{13} \mathrm{C}$ evidence. Mar Biol. 93: 615-625

Elmgren, R. A. (1978). Structure and dynamics of Baltic benthic communities, with particular reference of the relationship between macro- and meio-fauna. Kieler Meeresforsch., Sonderh. 4: 1-22

Feder, H. M., Day, R. H., Jewett, S. C., McCumby, K., McGee, S. Schonberg, S. V. (1985). Infauna of the northeastern Bering and southeastern Chukchi Sea. In: Outer Continental Shelf Environmental Assessment Program, Final Reports of Principal Investigators 32. US Dept of Commerce, NOAA, Washington, D.C., p. 1-120

Feeley, R. A., Massoth, G. J., Paulson, A. J. (1981). The distribution and elemental composition of suspended particulate matter in Norton Sound and the northeastern Bering Sea Shelf: implication for $\mathrm{Mn}$ and $\mathrm{Zn}$ recycling in coastal waters. In: Hood, D. W., Calder, J. A (eds.) The eastern Bering Sea shelf: oceanography and resources, Vol. I. Univ. Wash. Press, Seattle, p. 321-337

Findlay, S. E. G., Tenore, K. (1982). Nitrogen source for a detritivore: detritus substrate versus associated microbes. Science 218: 371-373

Fry, B., Sherr, E. B. (1984). $\delta^{13} \mathrm{C}$ measurements as indicators of carbon flow in marine and freshwater ecosystems. Univ. Texas Contr mar. Sci. 27.13-47

Graf, G., Bengtsson, W., Diesner, U., Schulz, R, Theede, H. (1982). Benthic response to sedimentation of a spring phytoplankton bloom: process and budget. Mar. Biol. 67: $201-208$

Grebmeier, J. M. (1987). The ecology of benthic carbon cycling in the northern Bering and Chukchi Seas. Ph.D. dissertation, Inst. Mar. Sci., Univ. Alaska, Fairbanks

Haflinger, K. (1981). A survey of benthic infaunal communities of the southeastern Bering Sea. In: Hood, D. W., Calder, J. A. (eds.) The eastern Bering Sea shelf: oceanography and resources, Vol. 2. Univ. Wash. Press, Seattle, p. 1091-1104

Iverson, R. L. Coachman, L. K., Cooney, R. T., English, T S., Goering, J. J., Hunt, G. L., Macauley, M. C., McRoy, C. P., Reeburgh, W. S. Whitledge, T. E. (1979). Ecological significance of fronts in the southeastern Bering Sea. In: Livingston, R. J. (ed.) Ecological processes in coastal and marine systems, Plenum Press, New York, p. 437-466

Jones, R. (1984). Some observations on energy transfer through the North Sea and Georges Bank food webs. Rapp. P.-v. Reun. Cons. int. Explor Mer. 183: 204-217 
Kowalik, Z., Matthews, J. M. (1982). The $M_{2}$ tide in the Beaufort and Chukchi Seas. J. phys. Oceanogr. 12: $743-746$

McConnaughey, T., McRoy, C. P. (1979). Food web structure and the fractionation of carbon isotopes in the Bering Sea. Mar. Biol. 53: 257-262

McManus, D. A., Kolla, V., Hopkins, D. M., Nelson, C. H. (1977). Distribution of bottom sediments on the continental shelf, northern Bering Sea. U.S.G.S. No. 759-C, US Dept of the Interior, Washington DC

McManus, D. A., Smyth, C. S. (1970). Turbid bottom water on the continental shelf of the northern Bering Sea. J. Sedim. Petrol. 40: 869-873

McManus, D. A., Venkatarathnam, K., Hopkins, D. M., Nelson, C. H. (1974). Yukon River sediment on the northernmost Bering Sea Shelf. J. Sedim. Petrol 44: 1052-1060

McRoy, C. P., Goering, J., Shiels, W. (1972). Studies in primary productivity in the eastern Bering Sea. In: Takenouti, A. et al. (eds.) Biological oceanography of the northern North Pacific Ocean. Motoda Commemorative Volume. Idemitsu Shoten, Tokyo, p. 199-216

McRoy, C. P., Tripp, R. B. (1986). ISHTAR Data Report No. 2 1985 Hydrographic Data, STD, Nutrients, \& Chlorophyll Inst. Mar. Sci., Univ. Alaska, Fairbanks

McRoy, C. P., Tripp, R. B. (1987). ISHTAR Data Report No. 4 1986 Hydrographic Data, STD, Nutrients, \& Chlorophyll Inst. Mar Sci., Univ. Alaska, Fairbanks

Mills, E. L., Pittman, K., Tan, F. C. (1984). Food-web structure on the Scotian Shelf, eastern Canada: a study using ${ }^{13} \mathrm{C}$ as a food-chain tracer. Rapp. P.-v. Réun. Cons. int. Explor Mer 183: 111-118

Nelson, C. H., Rowland, R. W., Stoker, S. W., Larsen, B. R (1981). Interplay of physical and biological sedimentary structures of the Bering continental shelf. In: Hood, D. W. Calder, J. A. (eds.) The eastern Bering Sea shelf: oceanography and resources, Vol. 2. Univ. Wash. Press, Seattle, p. 1265-1296

Pace, M. L., Glasser, J. E., Pomeroy, L. R. (1984). A simulation analysis of continental shelf food webs. Mar. Biol. 82 $47-63$

Parker, P. L., Scalan, D. (1987). Stable carbon and nitrogen isotope studies. In: Component C. Organic matter production and degradation on the shelf of the North Bering Chukchi Shelves. ISHTAR 1986 Progress Report, Vol. I Inst. Mar. Sci., Univ. Alaska, Fairbanks, p. 299-316

Parsons, T. R. K., Takahashi, M., Hargrave, B. T (1977). Biological oceanographic processes, 2nd edn. Pergamon Press, Oxford

Pearson, C. A., Mofjeld, H. O., Tripp, R. B. (1981). Tides of the eastern Bering Sea Shelf. In: Calder, J. A. (ed.) The eastern Bering Sea shelf: oceanography and resources, Vol. 1. Univ. Wash. Press, Seattle, p. 111-130

Peters, K. E., Sweeney, R., Kaplan, I. R. (1978). Correlation of carbon and nitrogen stable isotope ratios in sedimentary organic matter Limnol. Oceanogr 23: 598-604

Rohlf, F. J., Sokal, R. R. (1969). Statistical tables. W H. Freeman and Co., San Francisco

Rowe, G. T (1971). Benthic biomass and surface productivity In: Costlow, J. D. Jr. (ed.) Fertility in the sea, Vol. 2. Gordon and Breach Science Publisher, New York, p. $441-454$
Sambrotto, R. N., Goering, J. J., McRoy, C. P. (1984). Large yearly production of phytoplankton in the western Bering Strait. Science 225: 1147-1150

Schumacher, J. D., Aagaard, K., Pease, C. H., Tripp, R. B. (1983). Effects of a shelf polyna on flow and water properties in the northern Bering Sea. J. geophys. Res. 88 $2723-2732$

Smith, K. L., Laver, M. B., Brown, N. O. (1983). Sediment community oxygen consumption and nutrient exchange in the central and eastern North Pacific. Limnol. Oceanogr 28: 882-898

Springer, A. M. (1988). The paradox of pelagic food webs in the northern Bering Sea. Ph. D. dissertation, Inst. Mar. Sci., Univ. Alaska, Fairbanks

Stoker, S. W. (1978). Benthic invertebrate macrofauna of the eastern continental shelf of the Bering/Chukchi Seas Ph. D. dissertation, Inst. Mar. Sci, Univ. Alaska, Fairbanks.

Stoker, S. W (1981). Benthic invertebrate macrofauna of the eastern Bering/Chukchi continental shelf. In: Hood, D. W. Calder, J. A. (eds.) The eastern Bering Sea shelf: oceanography and resources, Vol. 2. Univ. Wash. Press, Seattle, p. $1069-1090$

Tenore, K. R. (1987). Nitrogen in benthic food chains. In: Blackburn, T H., Sirensen, J. (eds.) Nitrogen cycling in coastal marine environments. John Wiley and Sons Ltd. New York

Tenore, K. R., Cammen, L., Findlay, S. E. G., Phillips, N. (1982). Perspectives of research on detritus: do factors controlling the availability of detritus to macroconsumers depend on its source? J. mar Res 40: 473-480

US Geological Survey (1986). Water resources data Alaska Water Year 1985, U. S. G. S. No. AK/85-1, US Dept of the Interior, Washington, D. C

Valiela, I. (1984). Marine ecological processes. Springer-Verlag, New York

Walsh, J. J. (1980). Shelf-sea ecosystems. In: Longhurst, A. R (ed.) Analysis of marine ecosystems. Academic Press, New York, p. 159-196

Walsh, J. J., McRoy, C. P. (1986). Ecosystem analysis in the southeastern Bering Sea. Cont. Shelf Res. 5: 259-288

Walsh, J. J., McRoy, C. P., Blackburn, T. H., Coachman, L. W. Goering, J. J., Nihoul, J. J., Parker, P. L., Springer, A. L., Tripp, R. B., Whitledge, T E., Wirick, C. D., Henriksen, K., Andersen, P. (1988). The role of Bering Strait in the carbon/nitrogen flux of polar marine ecosystems. In: Rey, L., Alexander, $V$ (eds.) Marine living systems of the far North. E. J. Brill, Leiden (in press)

Walsh, J. J., Premuzic, E. T., Whitledge, T E. (1981). Fate of nutrient enrichment on continental shelves as indicated by the $\mathrm{C} / \mathrm{N}$ content of bottom sediments. In: Nihoul, J. C. J. (ed.) Ecohydrodynamics. Elsevier Scientific Publishing Co., New York, p. 13-49

Wassman, P. (1984). Sedimentation and benthic mineralization of organic detritus in a Norwegian fjord. Mar. Biol. 83: 83-94

Whitledge, T. E. (1986). Nutrient distributions, In: Component C. Organic matter production and degradation on the shelf of the North Bering/Chukchi Shelves. ISHTAR 1985 Progress Report, Vol. I. Inst. Mar. Sci., Univ. Alaska, Fairbanks, p. 159-177

Zenkevitch, L. (1963). Biology of the seas of the USSR. Interscience Publishers, New York 